Volume 5 Issue 2, June 2018

\title{
The Role Of Notary In The Making Of Franchise Agreements Toward The Business Actors In Order To Get Legal Protection Guarantee
}

\begin{abstract}
Eliani Safitri ${ }^{1}$, Justisia Pamilia Luberty ${ }^{2}$ and Aryani Witasari ${ }^{3}$
Abstract. Franchising is essentially a marketing concept in order to expand a business network quickly. Franchising is not an alternative, but one way that is as strong and strategic as the conventional way of developing a business. In a franchise agreement, the role of a notary is required even though the franchise agreement itself is a standard agreement without a notary. However, in order to make the deed of the agreement is more authentic, the role of a notary is necessary to ensure the legal protection. The research method used was normative juridical. Normative legal research is a legal research conducted by reviewing materials derived from various laws and other materials from various literatures. Based on the results of research and discussion, it can be concluded that the role of Notary is important in making the deed of the franchise agreement in addition to preventing the occurrence of misappropriation (negligence or default) of one party. The notary also ensures the legal protection of the deed of the agreement because it is made under the legal protection. The franchise is an engagement or agreement between two parties in which all provisions refer to Article 1313 of the Civil Code of the treaty, article 1320 of the Civil Code of the validity of the agreement and Article 1338 paragraph (1) of the Civil Code on the principle of freedom of contract.

Keywords: Notary; Franchise; Legal Protection.
\end{abstract}

\section{Introduction}

In the global era, most cities in Indonesia are trying to develop their economy and expanding economic activities, especially developing cities such as Semarang. By expanding their business, the city will continue to exist in economic and trade activities.

The emergence of globalization trends in economic or trade at this time cannot be avoided anymore. The occurrence of globalization is characterized by the more transparent world. It is as if the sovereign State becomes boundless with other sovereign States in the world, and has changed the face of economic life around the world, including Indonesia as well. Economic globalization with its free market will inevitably become part of everyday life in the near future. ${ }^{4}$

Likewise, with the existence of business Franchise that has spread to various cities, such as Indomaret. The increasing number of franchise outlets opened by both small and large entrepreneurs is a proof that the franchise business has spread throughout Indonesia. Furthermore, the Indonesia people are very open with the franchise business because not only the franchise business can be a livelihood but also products sold are included in the needs of the community.

\footnotetext{
${ }^{1}$ Student of Master Program (S2) of Notaries, Faculty of Law Universitas Islam Sultan Agung email: eliani.safitri@gmail.com

2 Students of Master of Law, Faculty of Law, Universitas Islam Sultan Agung email pamiliajustisia@gmail.com

${ }^{3}$ Lecturer of Faculty of Law UNISSULA

${ }^{4}$ Nindyo Pramono 2006 Bunga Rampai Hukum Bisnis Aktua/ PT Citra Aditya Bakti Bandung p. 150
} 
Indonesia is now beginning to show developments in the economic sector to achieve the national development goals. Although it has not made fundamental changes in its economy, but Indonesia is able to prove the rise of the post-crisis monetary crisis in 1998. It also can be seen more the emergence of local and foreign investors to invest in Indonesia as well as the development of capital markets in Indonesia. ${ }^{5}$

The presence of Franchise is an effort to achieve the development of the economy in Indonesia. Franchise also take a very large role and can support in economic and social development. The essence is to create jobs, improve the welfare of society, and can create economic stability of the nation.

At this time, the government is more concerned on balancing the business of small companies as one of the development strategy. Small companies of this sole proprietorship may cooperate with Franchise brand owners in franchising.

Further, it is clarified in Article 3 of the Government Regulation of the Republic of the Republic of Indonesia No. 42 Of 2007 regarding franchising, it explains that businesses can be classified as Franchise businesses, it must meet the standards of services and goods offered and made in written form, easy to learn and applied, growing support, and intellectual property rights that have been registered.

Franchising is not a new industry in Indonesia. Its juridical legality has also been known in Indonesia since 1997 with the issuance of government regulation of the Republic of Indonesia No. 16 of 1997 dated 18 June 1997 on Franchise, followed by Decree of the Minister of Industry and Trade No. 259 / MPP / Kep / 7/1997 dated 30 July 1997 concerning Provisions and Procedures for Registration of Franchise Enterprises. This Regulation was later amended by Government Regulation of the Republic of Indonesia No. 42 Of 2007 regarding Franchise and Regulation of the Minister of Trade No. 31 / M-DAG / PER / 8/2008 concerning Franchise Operation. ${ }^{6}$

The establishment of a Franchise itself will relate to a Notary, because notaries play a role in helping to create legal certainty and protection for society. Notary public as authorized to make authentic deed, as long as the authentic author is not specified for other general officials. Certainty and legal protection are visible through the authentic deeds, it makes as the perfect evidence in court. The perfect proof because the authentic deed has three evidentiary powers: the outward proof power (uitwendige bewijsracht), the formal proof power (formele bewijsracht) and the material proof power (materialele bewijsracht). ${ }^{7}$

Actually, in essence, the form of a deed becomes an issue, whether the deed is made under the hands or authentic deeds made before the notary, as long as the parties remain committed to carrying out the obligations and rights set forth in the deed. ${ }^{8}$

Notaries as public officers may also provide guarantees and legal protection through the formulation of authentic deeds that have been made. The Deed is also a reflection of the fulfillment and execution of rights and obligations between a legal subject and another legal subject. According to R. Subekti that "of a major civil case of evidence (evidentiary instrument) is writing, while in a criminal case of testimony". ${ }^{9}$

\footnotetext{
${ }^{5}$ http://jurnal.unissula.ac.id/index.php/akta/ accessed on 2 April 2018 at 13.45 WIB

${ }^{6}$ Anak Agung Deby Wulandari and Ida Bagus Putra Atmaja "perlindungan Hukum Bagi

Franchise Usaha Mikro Kecil dan Menengah dalam Bisnis Franchise". Law Journal Vol. 2. No.3 http://dh3m0echan.wordpress.com/perlindungan-hukum-bagi-franchise-usaha-mikro-kecil-danmenengah-dalam-bisnis-franchise/2017/11/29//accessed 4 April 2018 at 23.07 WIB.

${ }^{7}$ G.H.S. Lumban Tobing 1999 Peraturan Jabatan Notaris V Edition Gelora Aksara Pratama Jakarta p. 55-59

${ }^{8}$ R. Subekti Hukum Pembuktian 2007 Ed. XVI Padya Paramita Jakarta p. 25

${ }^{9}$ Ira Koesoemawati dan Yunirman Rijan 2009 Kenotaris Ed. I Raih Asa Sukses Jakarta p. 19
} 
From the above opinion, it can be understood that the partnership agreement is a mutual cooperation agreement both parties who are both involved in the agreement. So that the parties involved need to get legal protection, because each party in the partnership agreement has its own obligations. The Franchise Agreement has regulated the protection of intellectual property rights by agreeing on certain restrictions that Franchise must comply with. It is directly or indirectly demonstrated to protect the intellectual property rights of the franchisor. The author carefully examined the role of a notary as a general official in the deed of franchise / franchise agreement as well as knowing more clearly the legal protection of franchise / franchise business.

\section{Research Methods}

The research method used was normative juridical. Normative legal research is a legal research conducted by reviewing materials derived from various laws and other materials from various literatures. In other words, this study examined library materials or secondary data. ${ }^{10}$ This type of normative research was used in this study because this study departed from the existence of a void of norms. The void of the norm in question is the absence of norms governing the accountability of a notary in the deed of the franchise agreement to guarantee the protection of its law in accordance with the established law.

Types of data in use were primary and secondary data as well as techniques of processing and analysis of legal materials. The description technique describes the situation or event. In the description technique does not seek or explain the relationship, test the hypothesis or make predictions ${ }^{11}$. The description means any description of a condition or position of legal or non-legal propositions. In this research that is described is about the role of Notary in making the deed of franchise agreement to guarantee legal protection.

\section{DISCUSSION}

\subsection{Notary's Role in Franchise Agreement}

The role of a Notary in the making of a business agreement is to translate the business transactions that the parties wish to undertake and may accommodate the interests of the parties. Thereby, the notary provides a guarantee or legal certainty until the realization of the business contract is definitive. In this case, it is the will of the parties set forth in a notarial deed is really a manifestation of a deed of legal power and can be used as evidence for other third parties, even able to become the strongest evidence in court. Any contract made by the parties is always likely to have the potential for conflict or disputes. The disputes sometimes unavoidable due to misunderstandings, breaches of statutory regulations, broken promises, conflicting interests and/or losses to either party. The source of the conflict that often triggers a dispute is the bad faith of one of the parties, the mistake of interpreting the sentences in the contract, Force Majeure, default, monetary issues, timing and fines. In the contents of the contract, there are several chapters or sections of the article that govern a particular thing that is special related to the possibility of events that are not desired by the parties that will occur in the future. Therefore, it is necessary to

\footnotetext{
${ }^{10}$ Soerjono Soekanto dan Sri Mamudji 2007 Penelitian Hukum Normatif (Suatu Tinjuan Singkat) Rajagrafindo Persada Jakarta p. 13

${ }^{11}$ M. Hariwijaya 2007 Metodologi Teknik Penulisan Skripsi Tesis Dan Disertasi Azzagrafika Yokyakarta p. 48
} 
regulate the clause of dispute settlement in the business contract. The way that the parties usually solve these conflicts is settled in a familial way (musyawarah), and if it is unsuccessful, the problem can be solved through applicable legal procedures. Whether in the form of judicial (litigation), and outside of court (nonliterary) or also biased by Alternative Dispute Resolution (ADR).

The notaries suggested in the making of the contract deed of the business can really accommodate the interests of the parties. Besides, it also because the business contract that covers various things in connection with the current era of globalization. It is recommended that the notary to keep increasing his knowledge, especially those related to the law business contract. And it is advisable to the Notary before making a deed should really know and understand the intentions of the parties, so that all conflicts that are likely to arise can be anticipated and also all the wishes of the parties can be accommodated in the deed. Thus, the power of authenticity of Notary deed is maintained everywhere and under any circumstances. It is expected that the parties to the settlement of disputes which may arise in order to keep priority to deliberation and consensus, and if the possibility cannot be resolved also it is expected to take a nonlitigation settlement in order to reduce the cost and time long compared to the settlement in litigation (court). Therefore, the role of notary in a franchise agreement or agreement between two parties in which all provisions refer to Article 1313 of the Civil Code of the agreement, article 1320 of the Civil Code of the validity of the agreement and Article 1338 paragraph (1) of the Civil Code on the principle of freedom of contract.

\subsection{How is the Legal Protection to the Actors of Franchise Business?}

Legal protection is a protection granted to legal subjects in the form of both preventive and repressive tools, both written and spoken. Franchising is essentially a marketing concept in order to expand the business network quickly. Franchising is not an alternative but one way that is as strong and strategic as the conventional way of developing a business. Even the franchise system is considered to have many advantages, especially concerning funding, human resources (HR) and management. Franchise is also referred to as a very effective distribution channels to bring products closer to consumers through the hands of franchisees.

Article 1 Government Regulation of the Republic of Indonesia No. 42 Of 2007 regarding Franchise declares that: Franchise is a special right owned by an individual or a business entity to a business system with a business characteristic in order to market goods and / or services that have proven successful and can be utilized and / or used by another party under a franchise agreement.

Further Clarified in Article 3 of Government Regulation No. 42 of 2007 concerning Franchises, it is clear that businesses that can be classified as Franchise businesses must meet the following criteria: have a business characteristic, proven to be profitable, have a standard of service and goods and/or offered services made in written form, easy to teach and apply. Franchising is not a new industry for Indonesia, its legal jurisdiction has been known in Indonesia since 1997 with the issuance of RI Government Regulation No. 16 of 1997 dated June 18, 1997 concerning Franchise, followed by Decree of the Minister of Industry and Trade No. 259 / MPP / Kep / 7/1997 dated 30 July 1997 regarding Provisions and Procedures for Registration of Franchise Business. This Regulation is then amended by Government Regulation No. 42/2007 concerning Franchise and Regulation of the Minister of Trade No. 31 / M-DAG / PER / 8/2008 concerning Franchise Operation. 
Volume 5 Issue 2, June 2018

\section{CLOSING}

\subsection{Conclusion}

- The role of a notary is required in the deed of franchise agreement to prevent the occurrence of misappropriation (negligence or default) because the role of notary in the franchise agreement is also an engagement or agreement between two parties where all the provisions refer to Article 1313 of the Civil Code of the agreement, article 1320 Civil Code regarding the validity of the agreement and Article 1338 paragraph (1) of the Civil Code regarding the principle of freedom of contract.

- Legal protection of franchisors Article 1 Government Regulation of the Republic of Indonesia No. 42 Of 2007 regarding Franchise Clarified in article 3 of Government Regulation of the Republic of Indonesia No. 42 Of 2007 About Franchise explains that businesses that can be classified as Franchise business must meet the following criteria: has a characteristic of business, proven to have advantages, has a standard for services and goods and/or services offered are made in written form, easy to teach and apply. Franchising is not a new industry for Indonesia, its legal jurisdiction has been known in Indonesia since 1997 with the issuance of RI Government Regulation No. 16 of 1997 dated June 18, 1997 on Franchise, followed by Decree of the Minister of Industry and Trade No. 259 / MPP / Kep / 7/1997 dated July 30, 1997 regarding Provisions and Procedures for Registration of Franchise Enterprises. This Regulation is then amended by Government Regulation No. 42/2007 concerning Franchise and Regulation of the Minister of Trade No. 31 / M-DAG / PER / 8/2008 concerning Franchise Operation.

\subsection{Suggestion}

- In order to maintain the authenticity of the deed of the franchise agreement, the making of the deed of agreement shall be made in the presence of a notary. In the sense that the will of the parties set forth in a notarial deed is actually an embodiment of a deed of legal power and may be used as a evidence for other third parties, even the strongest possible evidence in court if a problem occurs in the deed of agreement.

- Under the protection of a strong law, it is clear that the franchise agreement is not an agreement contrary to the Law and Religion or otherwise but the treaty as the Act for the party making it and binding on both parties. Because the franchise agreement is actually a standard, it can be done under the hands but must follow the provisions in accordance with the Civil Code.

\section{References}

[1] Anak Agung Deby Wulandari and Ida Bagus Putra Atmaja "Perlindungan Hukum Bagi Franchise Usaha Mikro Kecil dan Menengah dalam Bisnis Franchise". Law Journal Vol. 2. No.3 http://dh3m0echan.wordpress.com/perlindungan-hukum-bagifranchise-usaha-mikro-kecil-dan-menengah-dalam-bisnisfranchise/2017/11/29//accessed 4 April 2018 at 23.07 WIB.

[2] G.H.S. Lumban Tobing 1999 Peraturan Jabatan Notaris V Edition Gelora Aksara Pratama Jakarta.

[3] R. Subekti Hukum Pembuktian 2007 Ed. XVI Padya Paramita Jakarta p. 25 
[4] Ira Koesoemawati and Yunirman Rijan 2009 Kenotaris Ed. I Raih Asa Sukses Jakarta.

[5] Soerjono Soekanto dan Sri Mamudji 2007 Penelitian Hukum Normatif (Suatu Tinjuan Singkat) Rajagrafindo Persada Jakarta.

[6] M. Hariwijaya 2007 Metodologi Teknik Penulisan Skripsi Tesis Dan Disertasi Azzagrafika Yogyakarta.

[7] Nindyo Pramono 2006 Bunga Rampai Hukum Bisnis Aktual PT Citra Aditya Bakti Bandung.

[8] http://jurnal.unissula.ac.id/index.php/akta/ accessed on 2 April 2018 at 13.45 WIB 